\title{
Saving the Planet for the Future: Sustainable Development?
}

\author{
Felix Amoh-Siaw* \\ College of Liberal Arts Shanghai University, PRC.
}

*Corresponding Author: Felix Amoh-Siaw, College of Liberal Arts Shanghai University, PRC.

\begin{abstract}
The debate between economic growth and environmental sustainability has persisted among scholars and policymakers since the 1970s. When the Brundtland Commission published its report in 1987, critics and supporters of sustainable development were expected to find common ground to discuss and agree on issues. However, as national GDPs continue to increase, does the depletion of the biosphere. This prompted the adoption of the SDGs by the UN General Assembly with the major objective of fostering economic growth and environmental sustainability for present and future generations. However, this move did not do much to address the environmental question as climate change is entering unprecedented levels. How does this reality reconcile with sustainable development, especially when the discussion is more focused on the future? Is sustainable development the ideal agenda to pursue in order to save the biosphere? These questions are explored by comparing the realities of the environment to the expectations of the environmental aspect of the SDGs. The paper then concludes that the definition representation of the concept of the "future" by the SDGs is vague and requires clarity. The environmental situation cannot be mitigated with the SDGs; alternative concepts are better options to be considered if there is such a thing as "future."
\end{abstract}

Keywords: Sustainable Development Goals, Economic Growth, Environmental Sustainability, Alternative Concepts, Degrowth, Future Generations

\section{INTRODUCTION}

Since the successes of the industrial revolution and the improvement in living conditions in Europe and European offshoots, the theory of economic development as the only panacea to our problems has become proven and institutionalized into the very fabric of our society. Neoliberal economists and their counterpart institutions like the IMF and the World Bank have spearheaded this task and made it prudent on third world countries, especially to embrace economic development through hefty loans and technical assistance. As a result, the Organization of Economic Cooperation and Development (OECD) reports the world's Gross Domestic Product (GDP) per capita since 1820 has increased considerably by tenfold, and so has the well-being of people( OECD, 2014, p. 57).

Concomitant with massive GDP growth and improved economic well-being is the skyrocketing demography. The world population has grown from 1 billion at the start of 1800 to more than 7 billion today, with about 5 billion increase since 1950 alone (OECD, 2014, p.37).

However, exponential economic and population growth comes at a considerable price. The biosphere, the very mechanism that supports life is not growing; it remains static, neither are the natural resources which are transformed into useful artifacts for consumption and economic growth. With an increase in $\mathrm{CO} 2$ emissions, warming of temperatures, rise in sea levels, extinction of plant and animal species, and an overall depletion of global diversity, we have consciously or unconsciously ushered in the "Anthropocene" - an epoch where our actions have had a tremendous and negative influence on the ecosystem(Steffen, et al., 2001). The human desire for affluence and technology, coupled with the astronomical rise in demography, have had a significant impact on the planet and made it utterly impossible to continue developing at the same speed and pace as before (Steffen, et al., 2001, p. 746).

The new developments require solutions; the planet needs to be salvaged from the damages caused by the human species, but at the same time achieve human well-being along the way-a dichotomy at its best. From the Brundtland Commission's report of 1987 to the 2012 Earth Summit in Rio de Janeiro, a supposedly perfect answer to the Janus-faced question seems to have been found in the concept of Sustainable Development - an answer which in itself sound contradictory(Borowy, 2014, p. 1). 
The Sustainable Development Goals, also known as global goals, were adopted as a replacement for the Millennium Development Goals (MDGs) by the UN General Assembly to solve this problem (Monkelbaan, 2019, p. 4). The goals have faced several criticisms. Some scholars state actors argue that the goals are too broad to be achieved within 15 years. Others also praise them as bearing the answer to the age-long question of how to achieve human development and environmental sustainability simultaneously.

Whether the SDGs will be achieved within the 15 years time frame is not the focus here but whether they are the right modules needed to achieve the most widely used and generally accepted definition of sustainable development, "development that meets the needs of the present without compromising the ability of future generations to meet their own needs" (Brundtland, 1987, para. 1).How do we strive to end poverty by 2030 through economic growth and, at the same time, prioritize saving the biosphere for the future when in fact, we know not the "what" and the "when" definitions of the future? In any case, why should we think about achieving environmental sustainability and exponential growth within the same continuum when they might be mutually exclusive?

This paper analyses the critical questions surrounding the SDGs. It neither focuses on the complexity and implementation challenges of the goals debate; nor their general acceptability across states, institutions, disciplines, and academia. It instead addresses the environmental question of whether the planet could be sustained for the supposed future while at the same time preaching exponential growth. It then directs the path towards some alternative concepts propounded to achieve real environmental sustainability and concludes that the underlying concept of SDGs is defeated right from its inception.

\section{SDGS: ECONOMIC GROWTH AND THE ENVIRONMENT}

The Sustainable Development Goals (SDGs) belong to the same category of international policy plans like the Millennium Development Goals (MDGs). Although the concept of Sustainable Development was not entirely new, it was not until the publication of the Brundtland Report, "Our Common Future," in 1987 that the concept became popular within the international political landscape. From the 1992 Earth Summit to the Rio 2012, the SDGs gradually gained traction as it was for the first time, mentioned in an official UN document (Rio 2012 outcome document) (Kamau, 2018, p. 70.).

Although the SDGs are not laws in themselves, their existences are grounded in already existing international law. The UNGeneral Assembly is a recognized institution under the UN Charter, and the declaration of "Agenda 2030" was also made in the Assembly with full recognition of the Charter and the Universal Declaration of Human Rights (UDHR). So in the spirit and letter of the Charter, the UDHR and other international norms, the SDGs were made (UNGA, 2015, para. 10\&1)

The Brundtland report of 1987, which is credited for giving the widely accepted definition of sustainable development as we know today, priced development and living standards above the environment, despite acknowledging how they complement and interact with each other.

"the concept of 'needs,' in particular, the essential needs of the world's poor, to which overriding priority should be given..."(Brundtland, 1987, para. 1).

If the needs of the global poor (which will require substantial environmental resources) should be accorded a priority, then environmental concerns are second in a pecking order. In the end, human needs will have to be satisfied before considering anything about the environment. The SDGs that were later adopted in 2015 also had similar underlying logic. The environment was treated as a subset of economic growth. Climate Action, for example, was not addressed by putting a stop to that that causes it, but through limits to emissions and other adaptive measures which more or less encourage economic growth (SDGs, 2015). The phrase "sustainable development" is itself indicative of an agenda towards development rather than environmental sustainability. It treats environmental conservation not as an end in itself but as a means towards an end-economic development. While this could be understood from the standpoint that many of the world's emerging economies cannot sacrifice their development for environmental concerns in Gandhi's famous question, "are not poverty and need the greatest polluters" it does not in any way justify unlimited growth " (Daly, 2007, p. 55). 
Moreover, as Herman Daly observes, when the economy grows, it does not grow into outer space, but into a limited biosphere whose variables are mostly non-renewable (Daly, 2007). By negotiating economic growth and environmental sustainability, The SDGscould be setting the ground for "uneconomic growth (Daly, 2007, p55.).

SDGs 13. A, for example, suggests the mobilization of $\$ 100$ billion annually from developed countries in order to intervene in the needs of developing nations (SDGS 2015). But how do developed nations raise this amount and, at the same time, conserve the environment? If the agenda is growing economies to solve economic problems, then it is relatively counterproductive. As Kothari et al. observe, the SDGs are particularly feeble on multilateral cooperations and rely heavily on them to provide the resources towards the transformation towards sustainability, knowing very well that their actions recount could cause more harm to the environment (Kothari, Demaria, \& Acosta, 2015).

A phenomenon that creates a problem cannot be used to solve the same problem it created. Granted that exponential economic growth of our time is the cause of environmental unsustainability, it is in no position to render solutions to the very problems it created - that would be similar to quenching petrol fire with more petrol just because it is liquid.

The results are what we see today-viz. using resources about 1.5 times the carrying capacity of the planet, potential high rise in temperatures leading to food insecurity, high and frequent tropical storms, and the inimical destruction to biodiversity if not checked(Borowy, 2014, p. 2). If these developments (economic growth) should continue, as one author succinctly put it, a peep through the window will be just what is needed to understand how "uneconomic" our "economic developments are...no definitions required!(Borowy, 2014, p. 2)

In the face of these arguments, it is established that economic growth (exponential growth) that is often prioritized by sustainable development could hardly coexist with environmental sustainability. At any given time, either one of the two must be sacrificed to make way for the other, or that which is often forgone is the environment.

\section{The Future in Perspective}

The SDGs use the same definition from Brundtland's report: "development that meets the needs of the present without compromising the ability of future generations to meet their own needs (Brundtland, 1987, para. 1)." The UN resolution which adopted the SDGs an also referred to a sure "future generations," emphasizing a strong determination to protecting the planet through sustainable consumption and climate action (UNGA, 2015, preamble).However, the simple question that comes to mind is, "what and when is the future"? Is it next year or the year after? Could it also be the next fifty, one hundred, five-hundred, one thousand or five thousand years to come? These questions are as crucial to the question of sustainable development as the question of the environment. In any case, how do we know what the needs of future generations when we have no clue how their thinking could influence their demands? Five hundred years ago, for example, who would have thought that this current generation would be so obsessed with a thing called smart phones or computers? Imagine if their population then was just as we have today ( 7 billion); imagine if they knew rare earth minerals like tantalum and tungsten could be combined with gold and platinum to produce electronic devices; imagine if they knew the use fossil fuels as we do today? Would we have still been able to enjoy this well-being as we have today? Probably not!

One author who posed similar questions about the scope of the "future" argued that it is easy to accept its connotations because of the natural proclivity to provide for unborn children and the fact that "future" generations are in no position to disagree with current generations (Borowy, 2014, p. 5). Yet the need for rendering it a definition irrespective allows for policy directions and investments to be made by the government towards their achievements, a sensation which the author argues led to the formation of the Brundtland Commission in 1983 with the task to develop strategies towards achieving development beyond the year 2000.(Borowy, 2014, p. 3). The legitimate question which remains is what is beyond 2000? The SDGs, as we have today, also refers to sustainability to the year 2030 and beyond. What exactly is beyond 2030? 
Of course, the universe will someday come to a halt; the "future" can neither be indefinite nor one year (Borowy, 2014, p. 2). But if humanity has existed on the planet for millions of years and kept its resources afloat to support our lifestyle today, then planning for future generations should consider similar things. If indeed there is going to be any such thing as sustainable development for future generations, then we should be aiming for years just around how long humankind has existed (either in the multiple thousands or a million at least) and not something so near. The simple logic is if Homo sapiens kept the planet for our consumption millions of years ago, then we should be stewards and keep it towards something close if not the same.

Unfortunately, such a long future is not what the SDGs account for in dealing with the environment. The 2015 Paris Agreement, for instance, pledged to maintain warming below $2^{\circ} \mathrm{C}$ above pre-industrial levels (Paris Agreement, 2015, Art. 2). The estimated period for the $2^{\circ} \mathrm{C}$ is the year 2100 (i.e., if achieved) (World Bank, 2014, p. 5). Granted that states commit to all obligations under the agreement and warming increases just by the $2^{\circ} \mathrm{C}$ by 2100 , then by extrapolation, one could say, at least for every century, there will be $2^{\circ} \mathrm{C}$ warming. If this figure is multiplied by five or ten (for 500 or 1,000 years), then we could expect an astronomical and life-threatening global average temperature of 24.9 and $34.9^{\circ} \mathrm{C}$ respectively, using the current global average temperature of $14.9^{\circ} \mathrm{C}$ as a gauge (Sharp, 2018).A more precise calculation even makes it worse. A place like North Carolina, which sometimes record summer temperatures of $42^{\circ} \mathrm{C}\left(109^{\circ} \mathrm{F}\right)$ (Armstrong, 2017) would be dealing with something in the region of $52^{\circ} \mathrm{C}$ and $62^{\circ} \mathrm{C}$ by the years 2440 and 2940 respectively. This is very worrying. In the Sahara and other areas of the tropics, the event could become worse: humans, plants and animals cannot survive in these temperatures when they do happen (all other things held constant).

These "deep into the future" situations are probably beyond the current paradigm of sustainable development. Maybe they seem so far away for anybody living now to care, but our indifference will not prevent them from happening. Alternatively, perhaps we assume those generations of people will find their way out. Let us hope they do, but if they do not, the blame will be on us, and we will be remembered as the generation that not only sent flora and fauna into extinction but its own human species.

Deciding how people will live for the next 1,000 years will be problematic, and so is deciding for the next forty or fifty years. Be as it may, there should be a model to work with; some target to be achieved somehow. A contradictory model like SDGs, however, could pose serious problems. It is time to look elsewhere for alternatives.

\section{Alternative Concepts?}

The realm of economic growth is not the way to go when environmental conservation is on the agenda. As economists, Kenneth Boulding remarked: "anyone who believes that exponential growth can go on forever in a finite world is either a madman or an economist" (The Economists, 2015). The planet has reached its capacity, and any attempt to finitely grow economies within a limited biosphere could be consequential in any logical sense. In this regard, Sustainable Development has lost the argument of being an alternative concept.

Different people have developed several other approaches at different times and places. These include BuenVivir from Latin America, Degrowth from Europe, Swaraj from India, and Ubuntu from South Africa(Kothari, Demaria, \& Acosta, 2015). These concepts might differ in strategies but have a common understanding of what and who is responsible for the environmental problem(Kothari, Demaria, \& Acosta, 2015). They thus all see everything wrong with what sustainable development sees nothing wrong with-exponential economic growth.

All the alternative concepts listed above do have the same goal but different procedures and paths towards their achievements as Kothari et al. observed. In lieu of this, I will delve into some of the specific policies suggested in different forms. Since their philosophical underpinnings are similar or same (they oppose economic growth and support social movements towards sustainable development no matter the different approaches), I deem all of them as equally important and worth considering.

Degrowth, which was born in France in 1972, is a renunciation movement against the semblance and fantasy of economic growth through hyper-production and consumerism (Kallis, Demaria, \& D'Alisa, 
2015 , p. 2). Today's degrowth is not so different from what it used to be before. The movement proposes an end to viewing growth as the panacea to societal problems and embracing the concept of humanity instead of using few of the limited earth's resources efficiently and differently through "sharing', 'simplicity' and 'conviviality (Kallis, Demaria, \& D'Alisa, 2015, p. 5)."'

The New Economist Foundation, a British economic and environmental think tank in 2010 published a report that dealt immensely with the current lifestyle of hyper-consumerism, which boosts GDP growth in what they referred to as "business as usual" (Spratt et al. 2010). They argued that unless the breaks are pulled on global opulence, and alternative approaches beyond orthodox economic approaches (degrowth) identified and pursued, then humanity could be heading towards destruction. If economic liberalization has failed to consistently deliver economic growth (as seen in the global financial crisis); if more than 2 million people still live in poverty today; if inequality is increasing, then alternative thinking and approaches must be sought, they stated(Spratt et al. 2010).

What they proposed, for example, is to make valuable things like water expensive and socially "useless" items like diamonds costly through planned revaluing. Just consider why people regularly change their closets. It is possible because the raw materials for making clothes like cotton and water are cheap. Imagine if tomorrow the costs of cotton and water increase by say $50 \%$, will the demand for clothes be the same? This is what is meant by making valuable things cheap and "less valuable" ones expensive through revaluing. Together with the redistribution of income, rebalancing of the market, localization of the market and economical irrigation of financial flows could cause GDP to reduce by three-fourth, and create an environmental and social value worth $£ 8.65$ trillion(Spratt et al. 2010, p. 4). Even if just half the value could be achieved by 2050, then it could double every forty years, and the planet could be saved from the burden of GDP and hyper-consumerism.

Professor Herman Daly, an ecological economist and emeritus professor at the School of Public Policy at the University of Maryland and a former World Bank senior economist, has also proposed similar alternative measures in the form of "degrowth."In his 1999 speech in Oslo, he recommended the five policies, which included: ending the accounting of natural capital as income, taxing resources instead of labor and capital, increasing capital efficiency, among others (Daly, 1999). One key recommendation is that of the shift in the tax system. If natural resources are taxed, then people could see their actual value and use it efficiently. Deforestation, for example, is on the rise, probably because fossil fuels for chain-saw machines are cheaper to extract. If oil companies were to be hugely taxed for the environmental damages caused by the land and living organisms, then the fuels will be costly and consumers will be discouraged from buying. This will then make chainsaw machines unattractive and people could resort to other means of making books rather than falling trees. The fact that deforestation was very low about until the invention of the chain saw underscores this argument.

During the last autumn, some 238 European scientists and a considerable number of European citizens rekindled degrowth and came up with three significant stratagems that, if implemented, could be a game-changer. In an article titled "Time to stop Growing and Grow up," they lamented the shortfalls of the current approaches towards environmental protection, as seen in international instruments like the Paris Agreement which together with all other efforts, prioritize economic growth over environmental sustainability instead of the reverse (Degrowth, 2019). In its place, they proposed placing tax redistribution and maximizing efficiency gains. They argue that GDP sacrifice both the people and the planet but with little emphasis on well-being. Coting examples from Bhutan and New Zealand, they made the point that prosperity could be achieved without growth that does nothing but exploits limited resources and destroys the environment.

Take also, for example, the Ubuntu philosophical concept of development. It is based on a community triad that rests on the living, the death, and the unborn (Ramose, 2015). The living, it is believed, has the same right as the future unborn child and that the Natural environment that supports the life of future generations must be sustained against the constant call for richness and profit-making "now." This could be challenged because it is religious and that not everyone believes in religion. However, the critical thing to learn from the philosophy is that it considers the long term future and imposes as a rule, on any generation not to deny the unborn generation their rights to life. It differs from what sustainable development offers in the sense that it does not recognize economic growth per se as the 
means to achieving well-being, but rather the spirit of community and sharing through redistribution of wealth to attain equality (Ramose, 2015). Ubuntu is thus "motivation for "degrowers"... appropriate ethical responses to the necessity to halt and reverse the global environmental change."(Ramose, 2015)

These alternatives approaches have also received their share of policy criticisms. Van den Bergh, for example, has criticizes the concept of degrowth for being unrealistic and having the tendency of creating a rebound effect if implemented (Van den Bergh, 2010). In his opinion, people voluntarily reducing their consumption in one type of commodity could cause them to consume other commodities once their disposable incomes remain constant. This argument is not valid because it treats degrowth (especially consumption and production degrowth) as an independent policy to be implemented when it must work with other sectors of the economy. None of the alternative policy recommendations provided anywhere could work in isolation from the other parts: Herman Daly's recommendation of "increasing capital efficiency cannot be achieved without the implementation of the other policies like "shifting of the tax system" (Daly, 1999). Likewise, the New Economist Foundation's "great transition" policies could also be challenged when not implemented in full (Spratt et al. 2010). The argument of presupposing that a concept is invalid because it would not be supported is not worth accepting. In any case, the mere fact that "degrowth" lacks support and difficult to achieve are not enough reasons for non-implementation.

The degrowth approaches, as discussed, have a lot in common, viz.--downscaling production and consumption, rethinking the domination of GDP in economic growth, redistribution of wealth, taxing resources instead of labor and capital and resource efficiency. They are critical concepts, one might say. But we are in critical times and will require critical solutions.

\section{CONCLUSION}

The SDGs are necessary for achieving economic development and alleviating poverty to an extent. But in terms of environmental sustainability, they do not fit the bid. The environmental promises, as seen especially in the Paris Agreement, if successfully achieved, could only manage the environment for some time but will breakdown for generations to come so long as it aims for exponential economic growth. Succinctly put, the SDGs in terms of environmental sustainability is only buying time. It sees the problem, but instead of solutions, it rather manages in it a "damage control" fashion. If the future matters to in the SDGs, then it should look very deep into yet unborn generations (like ten centuries and still far beyond). Its components fall short of such future considerations.

What is worse is the fact that a causative factor is at the same time used as a solution. The simple reasoning is that one cannot solve a problem by creating more problems, which could further lead to other problems. That is an absurdity.

Alternative concepts are not perfect either, primarily when they have not been implemented on a large scale to see their outcomes. Moreover, they might seem too drastic and unrealistic. The answer to such criticisms is that the notion of impossibility lies in our thinking, and as Herman Daly said, we are caught in a "lurking inconsistency" (Daly, 1999).If we can understand the real purpose of value, then we might as well realize how vague and vain our understanding of GDP growth is. Every solution is bound to create some challenges, at least at the onset. But with time, they could be surmounted. Saying alternative concepts are unrealistic is just a flimsy excuse for running away from the reality of 21st-century environmental problems.

Having said that, the SDGs should also not be demonized outright; the mere fact that it acknowledges the importance of the environment in human development is commendable. In the very short term, they are required to manage the situation, but we must be ready to switch towards some form of alternative approaches any time soon, maybe sooner, if the goal is ever to save the planet for a human future.

\section{REFERENCES}

[1] Zanden, J. L., Baten, J., Mira d'Ercole, M., Rijpma, A., Smith, C., \& Timmer, M. (2014). How Was Life? Global Well-Being since 1820. OECD Publishing.

[2] Steffen, W., Persson, A., Deutsch, L., Zalasiewicz, J., Richardson, K., Crumley, C., et al. (2001). The Anthropocene: From Global Change to Planetary Stewardship. Royal Swedish Academy of Sciences, 739-761. 
[3] Borowy, I. (2014). Defining Sustainable Development for Our Common Future:A History on the World Commission on Environment and Development (Brundtland Commission). Abingdon: Routledge.

[4] Monkelbaan, J. (2019). Governance for the Sustainable Development Goals: Exploring an Integrative Framework of Theories, Tools, and Competencies. Singapore: Springer Nature Singapore Pte.

[5] Brundtland, G. H. (1987). Report of the World Commission on Environment and Development: Our Common Future. Oxford University Press.

[6] Kamau, M., Chasek, P., \& O'Connor, D. (2018). Transforming Multilateral Diplomacy: the inside story of the Sustainable Development Goals. New York: Routledge.

[7] General Assembly. (2015). Transforming Our World: The 2030 Agenda for Sustainable Development. New York: United Nations.

[8] Sustainable Development Goals. (2019, October 15). Retrieved June 02, 2019, from https://sustainabledevelopment.un.org/sdg13

[9] Daly, H. E. (2007). Ecological Economics and Sustainable Development, Selected Essays of Herman Daly. Cheltenham: Edward Elgar Publishing.

[10] United Nations. (2015). Paris Agreement.

[11] The World Bank. (2014). Turn Down the Heat. Washington DC. World Bank Group.

[12] Sharp, T. (2018, April 23). Retrieved June 03, 2019, from https://www.space.com/17816-earthtemperature.html

[13] Armstrong, T. (2017, June 09). National Weather Service. Retrieved June 05, 2019, from https://www. weather.gov/ilm/heatwaves

[14] The Economists. (2015, July 1). Retrieved June 03, 2019, from http://worldif.economistcom/article/12121 / debate

[15] Kothari, A., Demaria, F., \& Acosta, A. (2015). Buen Vivir, Degrowth and Ecological Swaraj: Alternatives to sustainable development and the Green Economy. Society for International Development, 362-375.

[16] Kallis, G., Demaria, F., \& D’Alisa, G. (2015). Degrowth. In G. D'alisa, F. Demaria, \& G. Kallis, Degrowth: A Vocabulary for New Era (pp. 1-17). Abingdon/New York: Routledge.

[17] Spratt, S., Simms, A., Neitzert, E., \& Ryan-Collins, J. (2010). The Great Transition: A tale of how it all turned right. London: New Economist Foundation.

[18] Daly, H. E. (1999, June 15). Five Policy Recommendations for a Sustainable Development. Feasta Review 1.

[19] Degrowth. (2019, May 07). Retrieved June 06, 2019, from https://degrowth.org/2019/05/07/what-europeneeds-is-a-sustainability-and-wellbeing-pact/

[20] Daly, H. (1999). The Lurking Inconsistency. Conversation Biology, 693-94.

[21] Ramose, M. B. (2015). Ubuntu. In G. D’Alisa, F. Demaria, \& G. Kallis, Degrowth: A Vocabulary for a New Era. London and New York: Routledge.

[22] Van den Bergh, J. C. (2010). Five types of "degrowth" and a plea for "a growth." 2nd Conference on Economic Degrowth for Ecological Sustainability and Social Equity. Barcelona: Research and Degrowth.

\section{AUTHOR'S BIOGRAPHY}

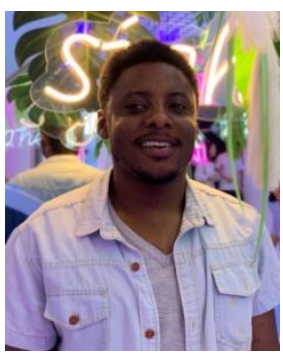

Felix Amoh-Siaw holds a Bachelor of Arts Degree in Political Science from the Kwame Nkrumah University of Science and Technology (KNUST), Ghana. Currently, he is a master's student of International Relations and Diplomacy in the College of Liberal Arts, Shanghai University, China.

His research interests are on the Responsibility to Protect (R2P), Genocides, Armed Conflicts and the Sustainable Development Goals (SDGs).

Citation: Felix Amoh-Siaw. "Saving the Planet for the Future: Sustainable Development?" International Journal of Humanities Social Sciences and Education (IJHSSE), vol 7, no. 3, 2020, pp. 1-7. doi: http://dx.doi.org/10.20431/2349-0381.0703001.

Copyright: (c) 2020 Authors. This is an open-access article distributed under the terms of the Creative Commons Attribution License, which permits unrestricted use, distribution, and reproduction in any medium, provided the original author and source are credited. 